\title{
Streptococcus suis okozta purulens meningitis különleges esete
}

\author{
Németh Anita dr. ${ }^{1}$ - Knausz Márta dr. ${ }^{1}$. Schmidt Péter dr. ${ }^{2}$ \\ ${ }^{1}$ Petz Aladár Megyei Oktató Kórház, Mikrobiológiai Laboratórium, Győr \\ ${ }^{2}$ Gyermekorvosi Alapellátás, Győr
}

\begin{abstract}
A szerzók egy gennyes meningitisben szenvedő férfi beteg esetét ismertetik, akinél az infekció hátterében a Streptococcus suis kóroki szerepét igazolták. A baktérium kolonizáló ágensként megtalálható különböző állatok (sertések, kérődzők, macskák, kutyák, szarvasok, lovak) felső légutaiban, tápcsatornájában, nemi szervein. A kórokozó elsősorban állatpatogén, de humán esetek is előfordulnak zoonoticus eredettel. A megbetegedés elsősorban szepszis, meningitis képében jelentkezik mind az állati, mind a humán esetekben. A betegség prevalenciája földrészenként igen eltérő, a legmagasabb Ázsiában. A megbetegedések kialakulásában alapvető különbség figyelhető meg az ázsiai, illetve európai és amerikai régiók között, melyet eltérő kulturális és étkezési szokások befolyásolnak. A baktérium megjelenésére hazánkban elsősorban foglalkozási megbetegedésként kell számítani, de a fellendülő turizmus következtében behurcolt esetek is előfordulhatnak. A kórokozó pontos mikrobiológiai diagnosztikájához elengedhetetlen a modern identifikálómódszerek megléte. A szerzók szeretnék felhívni a figyelmet erre a súlyos infekciót okozó baktériumra, ezért fontosnak tartják a szakirodalomban fellelhető ismeretek összefoglalását és közlését.
\end{abstract}

Orv Hetil. 2019; 160(1): 30-34.

Kulcsszavak: Streptococcus suis, zoonosis, foglalkozási betegség

\section{Special case of purulent meningitis caused by Streptococcus suis \\ Case report}

The authors describe the case of purulent meningitis of a male patient who has been diagnosed with the role of Streptococcus suis in the background of the infection. The bacterium is a colonizing agent in the upper respiratory, gastrointestinal tract, and genital organs of various animals (pigs, ruminants, cats, dogs, deer and horses). The pathogen is predominantly animal pathogenic, but human cases also occur with zoonotic origin. The disease occurs primarily in sepsis, meningitis, in both animal and human cases. The prevalence of the disease is very diverse in the continents, the highest is in Asia. There is a difference between the Asian and the European and American regions, which is affected by cultural and eating habits. The appearance of bacteria in our country is primarily due to an occupational disease, but also imported cases may occur, due to the emerging tourism. For the precise microbiological diagnosis of the pathogen, the existence of modern identification methods is indispensable. The authors want to draw attention to this bacterium that causes serious infections, so it is important to summarize and disclose the knowledge available in the literature.

Keywords: Streptococcus suis, zoonosis, occupational disease

Németh A, Knausz M, Schmidt P. [Special case of purulent meningitis caused by Streptococcus suis. Case report]. Orv Hetil. 2019; 160(1): 30-34.

(Beérkezett: 2018. július 6.; elfogadva: 2018. augusztus 19.)

\section{Rövidítések}

ARDS = (acute respiratory distress syndrome) akut légúti distressz szindróma; $\mathrm{CDC}=($ Centers for Disease Control and Prevention) az Amerikai Egyesült Államok Járványügyi és Betegségmegelőzési Központja; CRP = C-reaktív protein; $\mathrm{CT}=$ (computed tomography) számítógépes tomográfia; MALDITOF (matrix-assisted laser desorption ionisation-time of flightmass spectroscopy) mátrixasszisztált lézer deszorpció/ionizáció-repülési idő mérésén alapuló tömegspektrometria; NBS = (National Bacteriological Surveillance) Nemzeti Bakteriológiai 
Surveillance; OMSZ = Országos Mentőszolgálat; PAMOK = Petz Aladár Megyei Oktató Kórház; PCR = (polymerase chain reaction) polimeráz-láncreakció

A purulens meningitis halálozása a hatékony antibakteriális kezelés ellenére napjainkban is jelentős. Egy nagy esetszámú retrospektív tanulmány szerint a közösségben szerzett gennyes meningitis letalitási aránya $25 \%$ [1]. A betegség becsült incidenciája a fejlett országokban évi 2,6-6 eset 100000 lakosra számítva, de ez az érték gyakran magasabb a szerény anyagi körülmények között élőknél [2]. A kötelező gyermekkori védőoltások bevezetése mind a betegség gyakoriságát, mind a halálozási arányt csökkentette [3-5]. A lehetséges kórokozók előfordulási gyakorisága egyrészt az életkor, másrészt a földrajzi terület függvényében változik [6,7]. A 60 évnél fiatalabb felnőttek esetében a közösségben szerzett bakteriális meningitis $60 \%$-áért a Streptococcus pneumoniae felelős, majd gyakorisági sorrendben a Neisseria meningitidis (20\%), a Haemophilus influenzae (10\%), a Listeria monocytogenes (6\%) és a Streptococcus agalactiae (4\%) követi. A 60 év feletti korcsoportban az immunitás csökkenése következtében még gyakrabban fordul elő a $S$. pneumoniae (70\%) és a L. monocytogenes (20\%) [8]. Mindkét korosztályban 1-2\%-os gyakorisággal egyéb, ritkább kórokozók is előfordulhatnak. A geográfiai megoszlásra példaként említhetó a gyakori $A$-csoportú Meningococcus okozta járványok fellépése a szubszaharai régióban ('meningitis belt') [9].

A győri Petz Aladár Megyei Oktató Kórházban (PAMOK) 2018 januárjában, az influenzajárvány kellős közepén jelentkeztek gennyes agyhártyagyulladás tünetei egy férfi betegnél, akinek rövid kórtörténetét az alábbiakban ismertetjük.

\section{Esetismertetés}

A 48 éves férfi beteget az OMSZ szállította a PAMOK Sürgősségi Osztályára két napja kezdődött fejfájással, magas lázzal $\left(39-41^{\circ} \mathrm{C}\right)$, izomfájdalmakkal, egy napja tartó hányással, hasmenéssel, beszédzavarral. Anamnézisében komolyabb megbetegedés nem szerepelt. Vitális paramétereit tekintve vérnyomása 156/104 $\mathrm{Hgmm}$, pulzusa $117 / \mathrm{min}$, testhőmérséklete otthoni lázcsillapítás után $37,3{ }^{\circ} \mathrm{C}$, oxigénszaturációja $98 \%$ volt. A fizikális vizsgálat során éber, de dezorientált volt, a meningealis izgalmi jelek (Kernig, Brudzinski) pozitívnak bizonyultak. Felvételi statusában egyéb kóros eltérést nem találtak, testén kiütések, bevérzések nem látszódtak, duzzadt, fájdalmas ízületet nem észleltek. Felvételi laborvizsgálatából kiemelendő a 25,6 G/L fehérvérsejtszám és a 162,4 mg/L CRP. A mellkasröntgenen és a koponya-CT-n kóros eltérés nem ábrázolódott. Ezt követôen mikrobiológiai mintavételezések történtek (hemokultúra, liquor). A lumbálpunkció során közepes nyomással opálos agyvíz ürült. A liquor kémiai vizsgálatának eredménye a következó volt: sejtszám 750, fehérje $3,5 \mathrm{~g} / \mathrm{L}$, cukor $1,2 \mathrm{mmol} / \mathrm{L}$. A sürgősséggel elvégzett liquorgyorsteszt, mely a bakteriális meningitis fó kórokozóit azonosítja (Streptococcus pneumoniae, Streptococcus agalactiae, Haemophilus influenzae, Neisseria meningitidis A,C,, W135, Neisseria meningitidis $B, E$. coli Kl), negatív eredményt mutatott. A liquor Gram szerint festett kenetét mikroszkópban vizsgálva látóterenként 20-30 granulocytát és Gram-pozitív, 'lándzsa alakú' Diplococcusokat láttunk (1. ábra). A mikroszkópos kép alapján a Streptococcus pneumoniae kóroki szerepe tûnt a legvalószínúbbnek, de ezt a latexagglutinációs gyorsteszt nem igazolta. A betegnél még a Sürgősségi Osztályon dexametazon adását követően empirikus antibiotikum- (ceftriaxon-, ampicillin-) terápiát

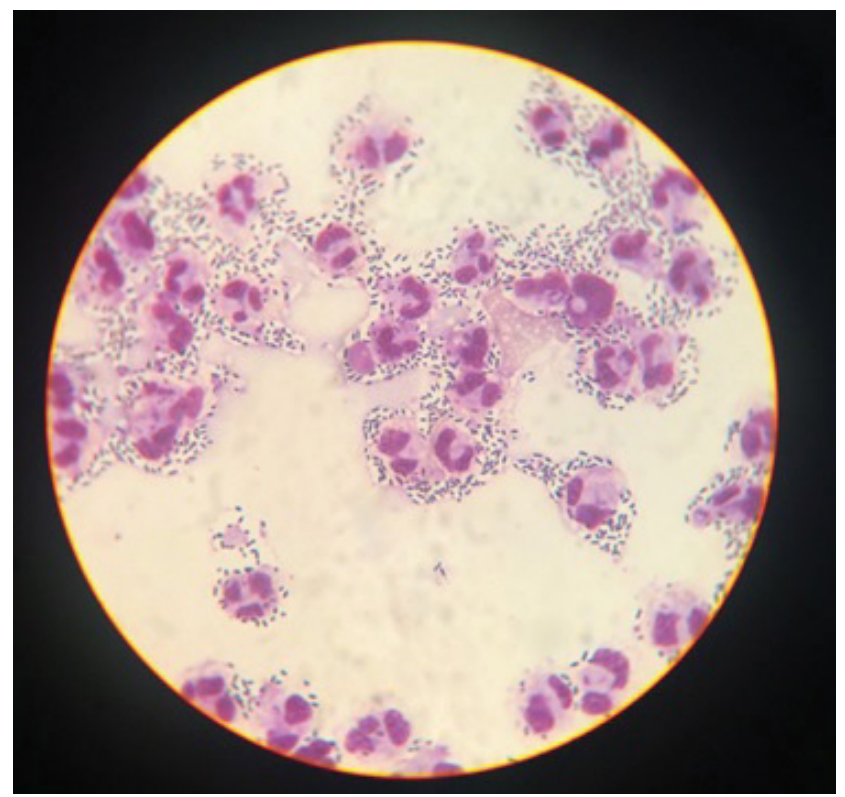

\begin{tabular}{l|l} 
1. ábra & Streptococcus suis-meningitisben szenvedő beteg liquorából ké
\end{tabular} szült Gram szerint festett kenet mikroszkópos képe

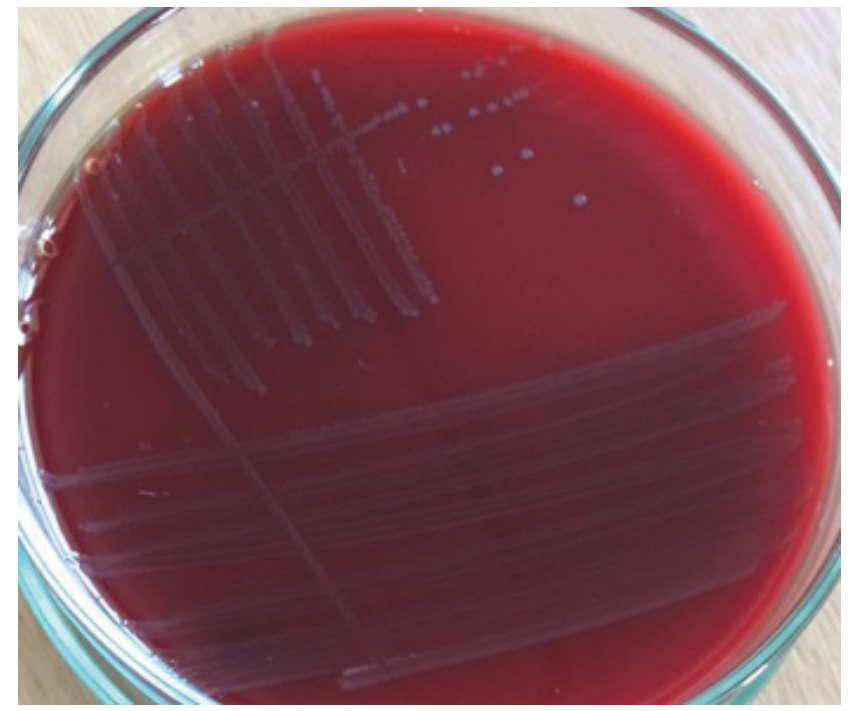

\begin{tabular}{l|l} 
2. ábra & Streptococcus suis-tenyészet véres agaron
\end{tabular} 
indítottak a területen szerzett purulens meningitis protokolljának megfelelően, majd a beteget az Infektológiai Osztályon helyezték el. A második ápolási napon a hemokultúrákból és a liquorból egyaránt egy $\alpha$-hemolizáló Streptococcus species tenyészett ki (2. ábra). Az identifikálást ID32 Strep (bioMérieux, Marcy-l'Étoile, Franciaország) félautomata gyári teszttel végeztük, melynek segítségével a kórokozó Streptococcus suisnak bizonyult. Megerősítés céljából a törzset az Országos Közegészségügyi Intézetbe küldtük, ahol MALDI-TOF vizsgálattal a S. suis-fertőzést alátámasztották.

A törzs az antibiotikumérzékenységi vizsgálata során penicillinre, ceftriaxonra érzékenynek bizonyult. Az eredmény birtokában az ampicillinterápiát felfüggesztették, és ceftriaxon-monoterápiát folytattak 14 napig. Az endocarditis lehetőségét a kardiológiai konzílium kizárta; audiológiai vizsgálat nem történt, mivel a betegnek ilyen irányú panaszai nem voltak. Az alkalmazott terápia mellett a páciens panaszai megszüntek, laborparaméterei regrediáltak, kontroll mikrobiológiai vizsgálatai (hemokultúra, liquor) negatívak lettek. Otthonába bocsátáskor és az egy hónappal későbbi kontrollvizsgálatok során semmilyen szövődményt nem észleltek.

Tekintettel a $S$. suis zoonosisban játszott szerepére a részletes heteroanamnézis során kiderült, hogy a beteg a családi gazdaságában mangalicákat tart, illetve hobbivadász. A megbetegedése előtt két nappal vaddisznót ejtett, és otthonában saját kezúleg dolgozta fel.

\section{Megbeszélés}

A S. suis Gram-pozitív, fakultatív anaerob coccus, amely elsősorban állatokban fordul elő, mint a normál-, kolonizáló flóra tagja, de súlyos infekciókat is okozhat bennük.
Humán megbetegedések is előfordulnak világszerte, melyek kialakulásában forrásként szerepel a fertőzött állattal vagy annak húsával való kontaktus. A baktérium kóroki szerepéről az első beszámoló Field és mtsai tollából származik. Elsőként 1954-ben ők jelentették a S. suis járványos előfordulását malacok között, melynek során az állatok agyhártyagyulladását, szepszisét és gennyes arthritisét észlelték [10]. 1968-ban Dániában közölték az első humán $S$. suis-fertőzést, azóta a szakirodalomban ismertetett emberi megbetegedések száma jelentősen megemelkedett [11]. A S. suis endémiás Délkelet-Ázsiában, ahol több meningitisjárványról számoltak be [12]. Kínában, Szecsuán tartományban 2005 júniusa és augusztusa között zajlott le egy nagyobb járvány emberek és sertések között, amelyben összesen 204 humán megbetegedést jelentettek, ezek közül 38 eset halállal végződött. A járvány során emberről emberre történő átvitelt nem tapasztaltak [13]. Az amerikai Centers for Disease Control and Prevention (CDC) 2012-ben végzett egy felmérést a $S$. suis globális prevalenciájára vonatkozóan, ennek eredményét mutatja a 3. ábra. 2012-ig összesen 1584 esetet jelentettek a világon, amely három járványkitörést is magában foglalt. A kórokozó prevalenciája Thaiföldön (8,21 eset/millió lakos) volt a legmagasabb, melyet Vietnam (5,40 eset/millió lakos) követett. Európán belül Hollandiában $(2,52$ eset/millió lakos) találták a legnagyobb értéket. A betegek átlagéletkora 51,4 év volt, a nemek arányát tekintve 76,6\% férfi. A megbetegedések kialakulásában alapvető különbség van az ázsiai, illetve az európai és amerikai régiók között, ami a kulturális és étkezési szokásoknak tudható be. Míg Ázsiában elterjedt a nyers vagy nem kellően hőkezelt sertéshús, belsőségek fogyasztása során szerzett fertőzés, addig Európában és Észak-Amerikában foglalkozási betegségként

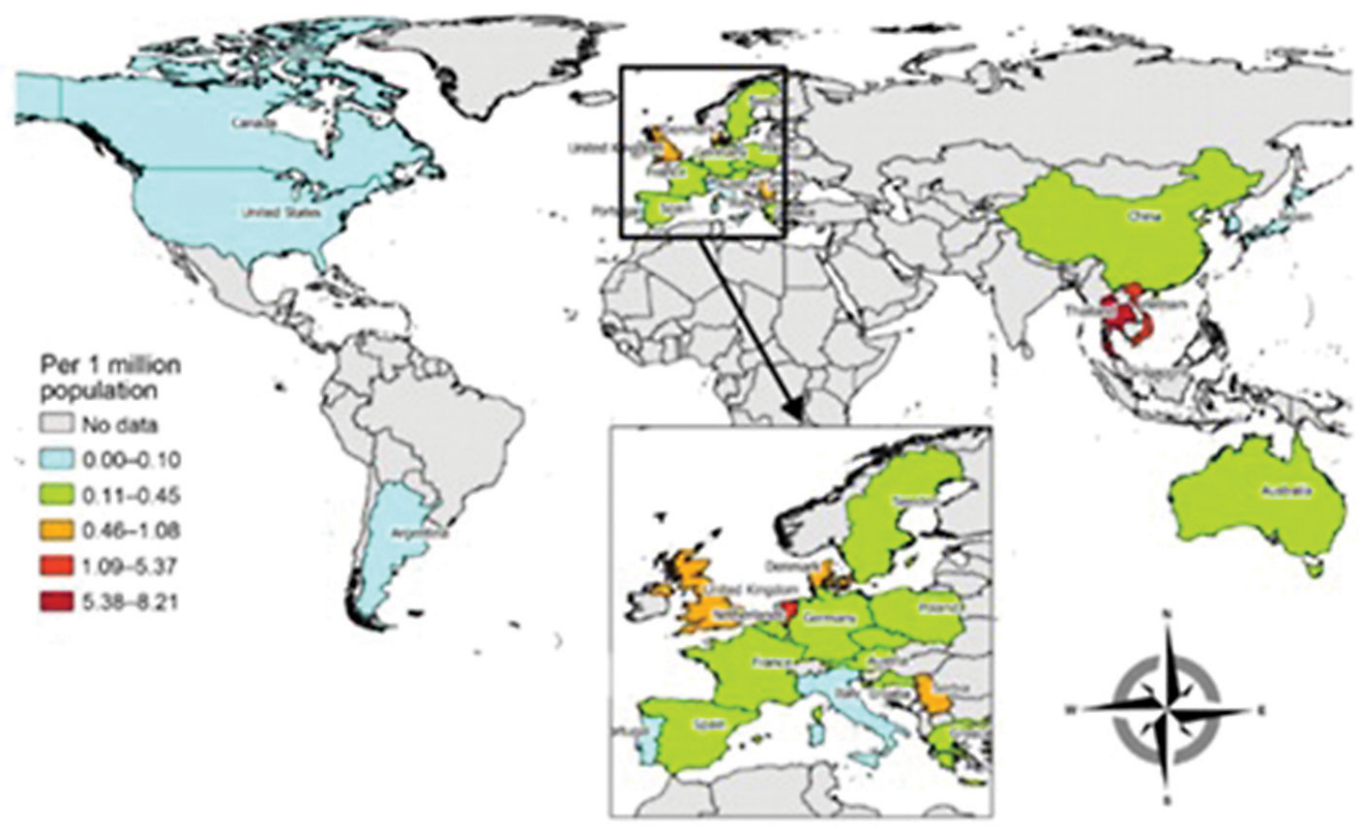

3. ábra

| A Streptococcus suis-infekció globális kumulatív prevalenciája [14] 
(hentes, vágóhídi dolgozó, állattenyésztő) vagy behurcolt esetként (turista) fordul elő [14].

A magyarországi megbetegedésekről ez idáig kongresszusokon hangzottak el beszámolók. Az elmúlt 15 évben a Nemzeti Bakteriológiai Surveillance (NBS) rendszerben 17 , invazív mintából (hemokultúra, liquor) kitenyésztett $S$. suis-izolátumot jelentettek, vagyis évente egy-két eset előfordulására lehet számítani [15, 16].

A baktériumnak 35 különböző szerotípusa ismert, ezek közül a 2-es szerotípus a legvirulensebb az emberekre és a sertésekre egyaránt [17]. A sertések egészséges egyedei a $S$. suis különböző vagy akár egyszerre többféle szerotípusát is hordozhatják az orrüregükben, manduláikban, felső légutaikban, nemi szerveiken és tápcsatornájukban, ők a baktérium természetes rezervoárjai. A házi sertés mellett a vaddisznókban is kolonizál. A sertéseken kívül a mikrobát más állatokból is izolálták (például kérődzők, macskák, kutyák, szarvasok, lovak) [18-22]. A kórokozó közvetlenül bejuthat a véráramba a bőr mikrosérülésein keresztül a sertéssel vagy sertéshússal történt érintkezés során. A másik lehetséges behatolási kapu a gastrointestinalis traktus, ebből kifolyólag a fertőzés másik nagy kockázati tényezője a $S$. suisszal kontaminált ételek fogyasztása [14].

A szakirodalmi adatok a humán megbetegedések lappangási idejét 3 órától 14 napig terjedő időszakban adják meg [11]. A jelentett humán megbetegedések 69,5\%ában a fertőzés fó klinikai manifesztációja az agyhártyagyulladás volt, ezt követte a szepszis $(19,5 \%)$, az endocarditis $(8,6 \%)$, a spondylodiscitis $(4,6 \%)$ és az endophthalmitis, illetve az arthritis $(2,9 \%)$ [14]. A S. suis okozta meningitis tünetei hasonlóak az egyéb gennyes bakteriális agyhártyagyulladáséihoz, beleértve a fejfájást, a lázat, a hányást, a meningealis izgalmi jeleket, bár leírtak olyan esetet is, amelyben a vezető tünet a szubjektív halláscsökkenés volt [11]. Néhány esetben toxikus sokk szindróma kialakulását is észlelték a megbetegedéssel kapcsolatban. Az e mögött álló molekuláris mechanizmusok, szuperantigének még további kutatások célpontjai, de azt valószínúsítik, hogy a patomechanizmus eltér az A-csoportú Streptococcustól [13]. A fertőzés egyik súlyos és gyakori szövődménye az idegi eredetű hallásvesztés, amely az esetek 39\%-ában lépett fel [14]. További súlyos szövődmény lehet még a dialíziskezelést igénylő akut veseelégtelenség, az ARDS és a consumptiós coagulopathia [11]. A S. suisszal fertőzött betegek letalitása $12,8 \%$ a legutóbbi vizsgálatok alapján [14].

A Streptococcusok speciesszintú azonosítása történhet hagyományos mikrobiológiai módszerekkel, mint például a tenyésztésen alapuló biokémiai tesztek. Napjainkban azonban a gyakorlatban gyári identifikálókitek használata terjedt el, melyek néhány óra alatt képesek azonosítani a kitenyésztett kórokozót. Ennél is modernebb és pontosabb módszerek a molekuláris biológiai technikák (PCR, MALDI-TOF). Ez utóbbi korszerű módszerek hiányában előfordulhat hibás azonosítás. A szakirodalmi adatok alapján a baktériumot több esetben Streptococcus species- ként, Enterococcus faecalisként, Aerococcus viridansként, $S$. bovisként vagy $S$. pneumoniaeként jelentik [11, 14].

A S. suis antibiotikumérzékenysége hasonló a genus többi tagjáéhoz. A tanulmányok a humán mintákból azonosított csaknem összes törzset penicillin-, ceftriaxon-, vankomicinérzékenynek találták. Penicillinrezisztenciát egyetlen humán esetben, illetve néhány sertésből származó izolátumnál írtak le. A törzsek $20 \%$-a bizonyult makrolidokkal szemben rezisztensnek, $83,2 \%$ volt tetraciklinrezisztens és az aminoglikozidokkal szembeni rezisztenciája is alacsony szintû. Mint minden súlyos bakteriális fertőzés gyanúja esetén, az empirikus antibiotikus terápiát késlekedés nélkül el kell indítani, az antibiotikum típusát a fertőzés lokalizációja szerint kell megválasztani. Például S. suis-meningitis esetén ugyanaz a terápia alkalmazandó, mint $S$. pneumoniae előfordulásakor, ami 2 g ceftriaxont jelent 12 óránként 14 napig. Endocarditis esetén, ha a kitenyésztett törzs penicillinérzékenynek mutatkozik, 24 millió NE kristályos penicillin adandó naponta. A klinikai javulás hiánya vagy relapsus esetén a terápia újraértékelése szükséges, keresni kell az intracranialis tályogot, metasztatikus fertőzést, szekunder nosocomialis fertőzést vagy gyógyszer-rezisztencia kialakulását. Néhány $S$. suis-meningitisben szenvedő betegnél 2 hetes penicillin- vagy ceftriaxonkezelés után relapsus kialakulását jelentették, de a hosszabb 4-6 hetes kezelés mellett ők is gyógyultak. Az irodalmi adatok megegyeznek abban, hogy meningitis esetén adjuváns kortikoszteroidkezelés szükséges a hallásvesztés és az egyéb neurológiai károsodás megelőzése érdekében [11, $14,23,24]$.

Esetünkkel a hazai orvostársadalom figyelmét kívántuk felhívni erre a „feltörekvo”” zoonoticus patogénre. A fertőzés etiológiai ágensének igazolásához elengedhetetlen a pontos anamnézis éppúgy, mint a korrekt mikrobiológiai diagnózis. A kétes esetekben vagy a Streptococcusokat speciesszinten nem rutinszerúen diagnosztizáló laboratóriumoknak az invazív mintákból származó törzset identifikálás céljából referencialaboratóriumba kell küldeni. Fontos felhívni a figyelmet a higiénés rendszabályok betartására a húsfeldolgozás során, még otthoni körülmények között is. A megbetegedések nagy része megelőzhető a megfelelően hőkezelt húskészítmények fogyasztásával és az egyéb specifikus rizikófaktorok csökkentésével.

Anyagi támogatás: A szerzők anyagi támogatásban nem részesültek.

Szerzôi munkamegosztás: N. A.: A kézirat összeállítása, az ábrák elkészítése, megbeszélés. K. M.: A magyar és az angol nyelvű összefoglaló elkészítése, megbeszélés. S. P.: Irodalomkutatás, formai követelmények. A cikk végleges változatát mindhárom szerző elolvasta és jóváhagyta.

Érdekeltségek: A szerzőknek nincsenek érdekeltségeik. 


\section{Irodalom}

[1] Durand ML, Calderwood SB, Weber DJ, et al. Acute bacterial meningitis in adults. A review of 493 episodes. N Engl J Med. 1993; 328: 21-28.

[2] Brouwer MC, Tunkel AR, van de Beek D. Epidemiology, diagnosis, and antimicrobial treatment of acute bacterial meningitis. Clin Microbiol Rev. 2010; 23: 467-492.

[3] McIntyre PB, O'Brien KL, Greenwood B, et al. Effect of vaccines on bacterial meningitis worldwide. Lancet 2012;380: 1703-1711.

[4] Thigpen MC, Whitney CG, Messonnier NE, et al. Bacterial meningitis in the United States, 1998-2007. N Engl J Med. 2011; 364: 2016-2025.

[5] Lakos A, Torzsa P, Ferenci T. Bexsero, a novel vaccine against meningococcus. [Bexsero, egy új, meningococcus elleni vakcina.] Orv Hetil. 2016; 157: 242-246. [Hungarian]

[6] Schuchat A, Robinson K, Wenger JD, et al. Bacterial meningitis in the United States in 1995. N Engl J Med. 1997; 337: 970976.

[7] Scarborough M, Thwaites GE. The diagnosis and management of acute bacterial meningitis in resource-poor settings. Lancet Neurol. 2008; 7: 637-648.

[8] Hussein AS, Shafran SD. Acute bacterial meningitis in adults. A 12-year review. Medicine (Baltimore) 2000; 79: 360-368.

[9] Moore PS. Meningococcal meningitis in sub-Saharan Africa: a model for the epidemic process. Clin Infect Dis. 1992; 14: 515525 .

[10] Field HI, Buntain D, Done JT. Studies on pig mortality. I. Streptococcal meningitis and arthritis. Vet Rec. 1954; 66: 453-455.

[11] Wertheim HF, Nghia HD, Taylor W, et al. Streptococcus suis: an emerging human pathogen. Clin Infect Dis. 2009; 48: 617-625.

[12] van Samkar A, Brouwer MC, Schultsz C, et al. Streptococcus suis meningitis: a systematic review and meta-analysis. PLoS Negl Trop Dis. 2015; 9: e0004191.

[13] Tang J, Wang C, Feng Y, et al. Streptococcal toxic shock syndrome caused by Streptococcus suis serotype 2. PLoS Med. 2006; 3: e151. Erratum e377.

[14] Huong VTL, Ha N, Huy NT, et al. Epidemiology, clinical manifestations, and outcomes of Streptococcus suis infection in humans. Emerg Infect Dis. 2014; 20: 1105-1114.
[15] National Bacteriological Surveillance Management Team. NBS Annual reports, 2002-2017. National Institute of Environmental Health. Budapest, Hungary. [Nemzeti Bakteriológiai Surveillance Adatfeldolgozó Csoport. A magyarországi mikrobiológiai surveillance eredményei, 2002-2017. Országos Közegészségügyi Intézet, Budapest, 2017.] Online: www.oek.hu [Hungarian]

[16] National Center for Epidemiology. General characterization of the epidemiological situation in Hungary. [Országos Epidemiológiai Központ. A hazai járványügyi helyzet általános jellemzése.] Epinfo 2008; 15: 594- 599. [Hungarian]

[17] Lun ZR, Wang QP, Chen XG, et al. Streptococcus suis: an emerging zoonotic pathogen. Lancet Infect Dis. 2007; 7: 201-209.

[18] Staats JJ, Feder I, Okwumabua O, et al. Streptococcus suis: past and present. Vet Res Commun. 1997; 21: 381-407.

[19] Marois C, Le Devendec L, Gottschalk M, et al. Detection and molecular typing of Streptococcus suis in tonsils from live pigs in France. Can J Vet Res. 2007; 71: 14-22.

[20] Huang YT, Teng LJ, Ho SW, et al. Streptococcus suis infection. J Microbiol Immunol Infect. 2005; 38: 306-313.

[21] Risco D, Fernández-Llario P, Cuesta JM, et al. Fatal case of Streptococcus suis infection in a young wild boar (Sus scrofa) from Southwestern Spain. J Zoo Wildl Med. 2015; 46: 370-373.

[22] Sánchez del Rey V, Fernández-Garayzábal JF, Mentaberre G, et al. Characterisation of Streptococcus suis isolates from wild boars (Sus scrofa). Vet J. 2014; 200: 464-467.

[23] Katona G, Farkas Zs, Hirschberg J, et al. Hearing loss after purulent meningitis in the mirror of adjuvant dexamethason therapy. [A purulens meningitist követő halláskárosodás az adjuváns dexamethason kezelés tükrében.] Orv Hetil. 1993; 134: 247249. [Hungarian]

[24] Bijlsma MW, Brouwer MC, Kasanmoentalib ES, et al. Community-acquired bacterial meningitis in adults in the Netherlands, 2006-2014: a prospective cohort study. Lancet Infect Dis. 2016; 16: 339-347.

\section{"Nube solet pulsa candidus ire dies." (Üzve ködöt ki szokott sütni ragyogva a nap.)}

A cikk a Creative Commons Attribution 4.0 International License (https://creativecommons.org/licenses/by/4.0/) feltételei szerint publikált Open Access közlemény, melynek szellemében a cikk bármilyen médiumban szabadon felhasználható, megosztható és újraközölhető, feltéve, hogy az eredeti szerző és a közlés helye, illetve a CC License linkje és az esetlegesen végrehajtott módosítások feltüntetésre kerülnek. (SID_1) 